\title{
Sport Voluntarism: Indicators of Sport Volunteers' Satisfaction and Motivation
}

\author{
Ranjan Weerakoon \\ Department of Sport Science and Physical Education, Faculty of Social Sciences, University Of Kelaniya \\ Email: ranjan@kln.ac.lk \\ Dr. Chaminda Abeysignhe \\ Department of International Studies, Faculty of Social Sciences, University Of Kelaniya \\ Email: cabeysinghe@gmail.com \\ Dr. Sarath Vitharane \\ Department of Sociology, Faculty of Social Sciences, University Of Kelaniya \\ Email: 1vitharana@yahoo.com
}

\begin{abstract}
The study was examining characteristics of volunteer motivation and factors responsible for the volunteer satisfaction using Bang and Challadurai's (2003) volunteer motivation scale and Kuhn and Guzley's (2002) volunteer satisfaction index. The sample was selected by using random and snowball sampling methods. A Likertscale online survey was used and administered $(n=185)$ to gain volunteer perception of their motivation and satisfaction associated with individual volunteer experience. The results of descriptive analysis indicate that interpersonal contact, career orientation, personal growth, community involvement and love of sport are the motivational factors encouraging volunteers to participate in sport volunteerism. Thus, multiple regression analysis reveals that Career orientation and personal growth best explained volunteer satisfaction with volunteer experience. In addition, volunteer satisfaction dimensions such as Group integration, Empowerment and Organisation Support are satisfied according to the perception of volunteers with volunteer experience. Thus, multiple regression analysis reveals that empowerment and organisation support are the most influencing factors towards volunteer satisfaction in their volunteer experience. Finally, concluded that most volunteers focus on satisfying their personal goals through participating in sport volunteerism. For further researchers can be recommended to do research using different methods such as mix methods, qualitative methods and could use different influencing factors to address the gap in literature of volunteer satisfaction and motivation.
\end{abstract}

Key Words: Satisfaction, Motivation, Volunteers, Sport volunteer organisations, and Volunteer management DOI: $10.7176 / \mathrm{EJBM} / 13-6-20$

Publication date:March $31^{\text {st }} 2021$

\section{Introduction}

Voluntarism can be defined as an individual dedication of personal time, energy, knowledge, and skills towards the benefits of other people, group or causes (Omoto et al., 2000; Wilson, 2000 cited in Chelladurai, 2006b). The work of Chelladurai (2006) asserts that voluntarism is a unique type of pro-social behaviour that typically takes place in organizational context. Furthermore, apart from the previous explanations Freeman (1997) has defined that volunteering activity as a form of work that is done despite any financial return. In an article by Brown (1999) defined that volunteering is a purposeful activity that has no force or productive value to the volunteers. However in contrast to the definition of volunteer by Freeman (1997), many other researchers have identified different reasons for volunteering such as social, career, rewords, interpersonal relationship, commitment and financial etc. (Bang, et al., 2012; Pauline \& Pauline, 2009; Bang \& Ross, 2009; Doherty, 2009; Cheung et al., 2006; Reeser et al., 2005; Clary et al., 1998; Cuskelly \& Boag, 2001; Clary \& Snyder, 1999; Matzler et al., 2004; Pauline, 2011; Finkelstein, 2007). In addition, Cnaan et al. (1996) argued that the reason for certain people to participate in volunteering activities is driven by the pay received at the end of participation and on the 
same time he identified that there are four dimensions of volunteering such as the voluntary nature of the act, the nature of the rewards, the auspices under which the work is performed, and the relationship between the beneficiaries of the act and the actor. These dimensions influence people to eagerly engage in voluntary activities. Thus, the typical voluntary work differs between countries, in the United States volunteer culture addressing citizen needs, and Anglo-Saxon countries have high rate of volunteer engagement because the tradition encourage people to engage in volunteerism (Hodgkinson, 2003). Also, social demographic backgrounds of volunteers which help to identify and establish effective recruitment and retention strategies (Bussell \& Forbes, 2001). Moreover, Social resource theory point out that some certain characteristics which influence higher rate of volunteering such as human capital (income level, level of education, professional position) and Social capital (number of networks, number of connections with other institutes). These motivational factors and characteristics should be well grasped by the organizations in order to manage their volunteers because volunteering activities take place in organization context. In co-operate sector, volunteers provide their time, knowledge, or skills as part of community service or social responsibility for activities to be done during the company time without any compensation or additional financial benefits. While volunteers in other sectors such as health care, leisure and sport do their volunteering basically without any tangible benefits (Bussell \& Forbes, 2001). These social, economic and cultural benefits of voluntary activities have systematically provided through organizations.

\section{Problem of Sport Voluntarism}

Volunteer retention is one of the major problems in sports sector; Casta et al. (2006) have shown that the volunteers contributing time towards sports sector has been decreased by $22 \%$ in Australia. The work of Taylor et al. (2008) asserts that volunteer retaliation is a major problem within sports clubs around the world. Thus, volunteer recruitment and retention are considerable problems in many countries (Breuer \& Wicker, 2011). As Weerakoon (2016) highlighted that data related to sports clubs in Scotland, shows that $68 \%$ of sports clubs unable to attract new junior members, $55 \%$ of them failed to attract senior members as well, and $41 \%$ of them failed to attract female members and also $34 \%$ of sports clubs have a major problem regarding recruitment of new members to their clubs in Switzerland. Furthermore, it is recorded that volunteers amalgamation to sports clubs have reduced by $15 \%$ in United Kingdom during the year 2002 to 2009 and also Active People Survey shows that participation of volunteers have reduced in terms of Swimming, Tennis, Football, Golf, Cricket, Basketball and Rugby (Nichols et al., 2016). In this regards Costa et al. (2006) reports that many researchers in human resource management have identified many contributing factors for employees to remain or quit the company, the one major factor of employees' retention is satisfaction (Weerakoon, 2016). Therefore present study aims to examine characteristics of volunteer motivation and factors responsible for volunteer satisfaction using Bang \& Challadurai's (2003) volunteer motivation scale and Kuhn \& Guzley's (2002) volunteer satisfaction index. There are two key objectives as (a) to understanding factors influence volunteers' satisfaction, (b) to discover the motivation factors and satisfaction dimension which influence sport volunteer satisfaction.

\section{Literature Review Definition of Motivation and Satisfaction}

In Sport management and management fields' researchers have drawn attention to the employee satisfaction and motivation over the years (Cole, 1992 Hannagan, 1995; Chelladurai, 1999; Costa et al., 2006; Silverberg et al., 2002; Kemp, 2002). Especially in the sport management sector, scholars have investigated volunteers' motivation and satisfaction around the world because most of world sport organisations and sport events run by the volunteers ( Bang et al., 2012; Pauline \& Pauline, 2009; Bang \& Ross, 2009; Doherty, 2009; Cheung et al., 2006; Reeser et al., 2005; Clary et al., 1998; Cuskelly \& Boag, 2001; Clary \& Snyder, 1999; Matzler et al., 2004; Pauline, 2011; \& Finkelstein, 2007). Management authors have explained that the motivation is a work related psychological motivation which basically focuses on the strength and direction of the employee's work related behaviour, because they use their energy to achieve different aims or are less enthusiastic which makes it considerably difficult for the managers (Hannagan, 1995, Robbins, 1997; Hoy \& Miskel, 1987). Furthermore, Cole (1992) defined that motivation is concerned with why people do things as well as which need or driving force is within a person. The process of motivation is a selection of alternatives which are chosen according to desires or goals. Chelladurai (1999) supported the above explanation and definition of motivation and argued that there are two classes of motivation theories where one class is called as Content Theories (e.g. Herzberg's, 1968 and Maslow's, 1943) which explains factors that influence individual motivations and the second one is called as Process Theory (e.g. Adam's, 1977 and Vroom's 1964) that indicates a person's choice of behaviour. On the other hand, motivation has a direct relationship with the employee satisfaction, Bang \& Reio (2012) have done a study of a non-profit sport organization which studied the volunteer's job satisfaction, motivation and effective commitment, the result indicates that motivation has a direct relation with job satisfaction 
and job satisfaction has an immediate relationship with values and affective commitment. Apart from this research, other academics in the management field have studied the relevance of job satisfaction. However, all definitions show the relationship between satisfaction and motivation. Rice et al. (1989) defined satisfaction as a psychological comparison process which compared current job experience against some personal standards (wanting, feelings, seeking of other past experiences, etc.). Thus, Balzer et al. (1990) defined that satisfaction is the feeling of an employee about her or his job or job experience in relation with a past experience, present expectation, or any available alternatives.

\section{Volunteer Satisfaction}

Scholars in the field of management have examined the satisfaction of volunteers in various contexts including social service, (Clary et al., 1992; Finkelstein \& McIntyre, 2005; Finkelstein, 2007; Galindo-Kuhn \& Guzley, 2002), park and recreation (Silverberg et al., 2001), and other events (Costa et al., 2006; Doherty, 2009; Farrell et al., 1998). According to these studies, which are evident that satisfaction is multi-faceted and can be entangled with commitment, motivation, intrinsic and external benefits as well as organization management elements? A study done by Finkelstein (2007) noted that satisfaction depends on the volunteer experience fulfilling the volunteers' goals at one set of experience. Similarly, Silverberg et al. (2001) supported to Finkelstein (2007) who found in their study of park and recreation volunteers' satisfaction is that both job environment and psychological needs met by volunteering. Green et al. (1998) have done a study regarding volunteers and role of their training in Sunbelt Indy Carnival which revealed the sense of belonging in a community and that volunteer commitment has a positive relationship and leads to volunteer satisfaction. On the other hand, volunteer training should be designed as an opportunity to build a sense of community among volunteers which provides opportunity for volunteers to share their opinions and experiences among others. The sense of satisfaction of work is a vital component of a volunteer job satisfaction such as relationship with co-workers, quality of supervision, quality of communication, and the effective supervision (Silverberg et al., 2002). Lavelle (2010) makes clear that volunteers work for the organization without any wages or compensation, although they have a unique expectation or belief concerning the organization, they might expect intrinsic rewards from the organization. Social Exchange Theory explained that people are doing volunteer to build relationships with each other or in the organization on comparing cost and rewards, when these benefits are perceived much greater than the cost, individuals relate more and develop a closer relationship with the person or organization (Ben-Zur et al., 2005). In addition, Bang et al. (2012) and other researchers have highlighted that the relationship between volunteers' satisfaction and organization commitment (Feldman, 2000; Yousef, 2002 \& Cnaan \& Goldberg-Glen, 1991).

Researchers have investigated and found various factors that influence the volunteers' satisfaction in relation to their fields. In addition, researchers have developed a reliable instrument that understand and recognize volunteer satisfaction as multi-faced, Galindo-Kuhn \& Guzley (2002) have introduced Volunteer Satisfaction Index (VSI) utilizing previous studies which have done by different researchers in various volunteering study fields. The VSI model consists of 40 items which measure five dimensions of volunteer satisfaction such as communication quality, organizational support, participation efficacy, work assignment, and group integration. Preston \& Brown (2004) investigations' results show that volunteer satisfaction is now in a higher level than the average satisfaction. The findings of previous study of Pauline (2011) has provided results in regards to supporting the reliability and validity of Volunteer Satisfaction Index. A number of studies have been used in a multidimensional Volunteer Satisfaction Index into different settings and cultures (Boezeman \& Ellemers 2007; Chacon et al. 2007; Netting et al., 2004; Preston \& Brown 2004; Wong et al., 2011). The findings of the studies have revealed that more factors beyond the practicality of instrument, satisfaction can impact other aspects such as commitment, pride in the organization, time spent volunteer and longevity of service (Boezeman \& Ellemers, 2007). Furthermore, the instrument has been tested in different cultural contexts, Wong et al. (2011) have used this instrument in Chinese population, the results show that VSI was a psychometrically sound measure of volunteer satisfaction as well as these findings that are specific to the Chinese community andsuch factors are uncovered by Galindo-Kuhn and Guzley (2002) which is more focused on personal benefits gain from volunteering such as feeling of empowerment and to obtain the organization's support. In contrast, the study Wong et al. (2010) has indicated that volunteering is more concern about the interpersonal relationship. These evidences have realized that satisfaction can be different throughout the world and may be based on cultural variation. While the instrument has been applied in different context and cultures around the world, however, the construct instrument from previous studies has not been used altogether but used separately in different studies within sport sectors, most of them have been done in sports event field (Costa et al., 2006; Kemp, 2002; Bang et al., 2012; Bang \& Ross, 2009). 


\section{Volunteerism in Sport Industry}

The voluntarism still remaining the critical component of sport event and sport organisation which is of utmost importance for running sport event and many sports organisations (Bang \& Chelladurai, 2009; Chelladurai \& Madella, 2006; Cuskelly \& Boag, 2001; Cuskelly et al., 2006; Farrell et al., 1998; Green \& Chalip, 1998; Allen \& Shaw, 2009). Sports have a strong subculture, therefore people often attract to the sport volunteering, and also there is a sense of sociability and community that develops from the interaction among the volunteers and staff (Fairley et al., 2007). As Green \& Chalip (1998) perceptively states volunteer would be value their experience and their sense of involvement which has an interation and who is interested in the sport subculture. Researchers who are in the sport management sector have done studies by using social exchange theory which noted that a sense of community for volunteers is a predictor of volunteer retention and satisfaction (Costa, et al., 2006). Current research in satisfaction has provided evidence of overall satisfaction among the volunteers with their experience. A research that has been done in 1996 by Canadian women's curling championships indicate that volunteers were satisfied with their overall experience although more particularly, communication with other and recognition of organisation are significant factors of their overall satisfaction (Pauline, 2009). Thus, Larocque et al. (2002) reported that volunteers have high level of overall satisfaction with their experience in 2001 Francophone Games. However, volunteers were more satisfied with their quality of team and recognition from organisation and less satisfied with quality of service and responsibilities they were assigned. From the self-determination perspective, they explained that people's psychological needs are satisfied within the sport event or sport organisation activities, which lead to volunteers' positive commitment to the organisation. Therefore, an organisation has to create strategies for manful experience, the ability to make volunteers to feel responsible, and also to reward their positive outcomes may result in an enhancement in the volunteers' satisfaction and motivation, while at the same time, that will encourage individuals to volunteer in future events. In addition, Self Determination Theory suggests that a positive experience of volunteers at sport events positively influence volunteer satisfaction (Bang \& Ross, 2009). In a managerial perspective Farrell et al. (1998) stated that other organisational contingencies influence employee's satisfaction such as organisation environment, positive feedback, and better training and development. Therefore, sport managers should make an effort to satisfy volunteers' motivation and at the same time, try to understand what factors influence the most in volunteers' satisfaction which will be useful for future volunteer attraction to sport events. The volunteer managers' primary responsibility is recruiting and training volunteers. However in that process, managers should make sure to match the interest and ability of individual with the task performance (Williams et al., 1995). On the same time volunteers were satisfied with factors relevant to their contribution aspect while benefitting themselves and others, and also be focused in the relationship between motivation and satisfaction.

\section{Interrelation between Motivation and Satisfaction}

Many studies have been reported a positive correlation between satisfaction and motivation. A study has done in 2002 winter Olympic and Para-Olympic Games about the healthcare volunteers' motivation and satisfaction which results show that there is positive correlation between motivation and satisfaction, however physician and non-physician volunteers have several different motives, physician volunteers have low mean motivation in comparison with non-physician volunteers (Reeser et al., 2005). The work of Farrell et al. (1998) assert that volunteer motivation has a direct relationship with job satisfaction, as well as the study found out that volunteers are motivated to exchange their time and effort for the objective of meeting their personal goals and desires. Bang \& Ross (2009) exaggerates that relationship between motivation and satisfaction in special sports events, the multiple-regression test reveals that three motivational factors such as expression of values, career orientation, and love of sport are mostly affects to volunteer satisfaction. Self-Regulation Theory suggests that satisfaction of individuals' psychological needs promotes future motivation. Furthermore, Kemp (2002) identify factors that volunteers motivate to volunteering at mega sport events such as Pride in their country, its culture, social contact and friendship and desire to feel valued. These few researches have been done for understand the relationship between satisfaction and motivation, while many other researchers have done studies to understand nature of sport volunteers' motivation and factors influencing to sport volunteer motivation. Basically, volunteers are providing their time and effort for different types of reasons. From ancient way of understanding, the motivation has been based on altruism and selflessness (Phillips, 1982; Rehberg, 2005). Volunteers are doing volunteering basically for help others. Although Rehberg, (2005) noted that volunteers are involved in volunteering for special expectation and that could be more project oriented as well as depend on content of volunteer involvement. Furthermore, volunteers are motivated in sports where a direct or indirect benefit to themselves or their family members are expected (Silverberg et al., 2002). The work of Shibli et al. (1999) asserted that volunteers from the United Kingdom are doing volunteering for their personal benefits which has included a connection to their personal needs or interests and with the needs or interests of their family and friends. In addition, volunteers are involved in volunteering activities in a strong altruistic manner, although primary reasons 
for volunteering are not altruistic but to meet a need of volunteer. Another study conducted in healthcare industry that has identified reasons for joining an organization as a volunteer not only includes altruistic motives, but financial motives as well (Farmer \& Fedor, 1999). Furthermore, results of a study of volunteer motivation and demographic influence at professional tennis event mention that volunteers were strongly motivated by the material and purposive factors and demographic factors do not significantly affect the motivation to volunteer (Pauline \& Pauline, 2009). The literature related to volunteer motivations has suggested complex system of reason that people volunteering in events or organisations.

\section{Motivation and Satisfaction Frameworks}

In order to consider all the motivational issues, Cann \& Goldberg-Glen (1991) have done a study reviewing 27 other motivation-related studies and collected other additional data from a sample of 258 volunteers and 104 non volunteers. After the analysis of the data, the authors have planned in categorising two or more models for volunteering motivations, the analysis consistent 22 items that unidimensional scale name as motivation to volunteer (MVS) which has reflected both altruistic and egoistic motivations. However, there is no clear distinction between altruistic and egoistic motivations. Then after, research by Clary et al. (1998) suggested that functional analysis of voluntarism supporting to understand different underline of motivational process. There are six generous motivational categories that facilitated the involvement in voluntarism such as values (express altruistic and humanitarian concern for other), understanding (learning knowledge, skills, and abilities), social (opportunity to be friend with others and be a part of activity viewed important to others), career (obtain experience), proactive (mitigating guilty and understand how to manage problem) ego-growth and development (Clary et al, 1998). While adapting to the studies of Clary et al. (1998), Farrell et al. (1998) investigated volunteer satisfaction and motivation at the women's curling championship, where results suggested that a new scale for measure volunteer motivation which call as Special Event Motivation Scale (SEVMS), which is used 28 items to build this model. The new model introduces four categories of volunteer motivation such as purposive (to contribute to community and event), solidary (social interaction, group identification and network), external tradition (family tradition, use free time develop individual career), and commitment (linking personal expectation and skill). Supporting to this scale few other scholars (Grammatikopoulos et al., 2006; Twynam et al., 2002; Williams et al., 1995) have done studies at special sport events. One of the studies done by Willams et al. (1995) at the world cup downhill skiing event, that has reported most importance motivation for resident volunteer, were supporting to national team, improving community spirit, and strengthen the community image, this analysis basically rated the items and has not tested its validity and reliability of SEVMS. However, Twynam et al. (2002) have tested SEVMS model using event volunteer at Star Choice World Junior Curling Tournament. Similarly, a study has done in Greek volunteering by using SEVMS, suggesting that motivation can be explained by using this specific independent factors.

To expand the context of volunteer motivation Bang \& Chelladurai (2003) discovered that six volunteer motivation factors intentional sport event, 2002 FIFA world cup which is called as Volunteer Motivation Scale for International Sporting Events (VMSISE). That five factors as follows: expression of values (concerning others, success of the event and society), patriotism (Love of country), interpersonal contact (meeting, interacting people), personal growth (obtain useful new perspectives), extrinsic rewards (uniforms, food, accommodation and admission). The study of Bang and Chelladurai's (2003) depicted that patriotism is a unique motivation factor of international sporting event, as well as pattern of motivation of international sporting event different that other context of volunteering. In particularly, volunteers are engaging in international sporting events are likely motivated by patriotism to help their country to run an event successfully and gain international prestige. However, Bang \& Chelladurai's (2003) study has not investigated all the factors that have influenced volunteering in international sport events. However, avoiding that limitation Bang \& Ross (2009) have extended similar study in 2004 Twin City Marathon which has added new factors as the fondness of sport in Bang \& Chelladurai's (2003) VMSISE volunteer motivation scale. The results have been indicted that expression of values, career orientation, and appreciation of sport are the most influence motivation factors for the volunteer satisfaction.

\section{Methodology}

The purpose of the current study is examining the characteristics of volunteer motivation and factors responsible for the volunteer satisfaction by using Bang \& Challadurai's (2003) volunteer motivation scale and Kuhn \& Guzley's (2002) volunteer satisfaction index. To achieve this purpose, this research study is based on inductive research approach and based on primary sources of data, which were collected by using quantitative research approach. 


\section{Data Collection}

Current study has collected data using random sampling method (Pauline, 2011) which was a probability sampling technique where existing study subjects are recruited among the sport volunteers around the world. Therefore, questionnaires were distributed through Facebook social media among all the volunteers to keep high level of reliability and validity.

The online questioner was published on Rio 2016 Olympic volunteer facebook page and International Olympic committee's volunteer facebook page as well as using snow ball sampling system to spread out the questionnaire all over the world. Thus, the online questionnaire link was sent to the sports councils of University of Kelaniya and University of Suberagamuwa in Sri Lanka to distribute among their volunteers as well as sent to Northumbria sport central's volunteers. Researcher has collected 185 responses from sample population after one month. The questionnaire was focused to measure perception of sport volunteers' motivation and volunteer program experience in relation to their level of satisfaction. The questionnaire method was selected as major means of collecting data because it is economical, time saving and this method is very popular and highly applicable in scientific empirical researches (Kemp, 2002). And also, in order to get a deeper understanding, and for more clarification it was intended to collect data from secondary sources as well.

\section{Data Processing and Scaling}

The questionnaire consists of four major sections such as Demographic, Motivation, Satisfaction factors and overall Satisfaction. The Demographic part consists of three items such as Gender, Age and Level of Education, the second part of the questionnaire consists of 20 items which were divided in to five major parts such as Interpersonal contact, Career orientation, Personal Growth, Community Involvement and Love of Sport, the next part consists of 19 questions and it was divided in to three main parts such as Group Integration, Empowerment and Organisation Support and final parts were dedicated to measure the overall Satisfaction of volunteer experience.

As mentioned through overseeing the volunteer Motivation and Satisfaction questionnaire, Likert Scale questionnaire which has been used in this study consists of five boxes ranging from Strongly Disagree (1) to Strongly Agree (5) and from very dissatisfied (1) to very satisfied (5). Under each question the respondents were requested to select one of the five boxes and the ratings were collected and analysis.

\section{Data presentation and Analysis}

In this research numerical data were collected and analysed and the empirical data were examined by regression analysis, correlation, descriptive measures including mean, mode, and Standard deviation. Similarly, all the averages in relation to each variable with respect to sample were calculated in a systematic way using IBM Statistics SPSS 21. The mean value was calculated by dividing the total of the scores obtained from all the questions related to a particular variable by the number of questions asked in relation to that particular variable. The mean values of each variable were interpreted as follows: Highest score of an individual in relation to Motivation and Satisfaction suggests an individual's Motivation and Satisfaction is high, while the lowest score suggests that the individual Motivation and Satisfaction is low. The Cronbach's Alpha coefficient for the 9 items (Likert Scale Questions) is .919, suggesting that the items have relatively high internal consistency. (Note that a reliability coefficient of .70 or higher is considered "acceptable" in most social science research situations (Andrew et al., 2011). 
Independent Variable

\section{Motivation Factors}

Community involvement

Interpersonal Contact

Career orientation

Personal Growth

Love of Sports
Dependent variables

Satisfaction
Independent Variables

\section{Satisfaction Factors}

Empowerment

Organisation Support

Group Integration

\section{Figure 1: Conceptual Frame Work}

\section{Data Presentation and Analysis}

The presentation and analysis of empirical data were collected for the purpose of the study of factors influencing volunteer satisfaction. The major part of the data that have been used in this study are collected through the outcome of questionnaires distributed among the Sport volunteers around the world. Firstly, the descriptive statistics on demographic factor and impact of Motivation dimensions and Satisfaction dimensions are presented and explained. Then, the conceptual model was scientifically tested and the result was interpreted in order to provide a clear understanding on the relationship between the variables being studied under this research study.

The below table 01 shows the socio-demographic characteristics of the sport volunteers from all around the world that comprise the study sample. As seen in the table 01, the sample comprises primarily female volunteers (over 55\% of volunteers are female and around $41 \%$ of volunteers are males). Also, most of the respondents (34.9\%) are aged between $24-26,29 \%$ of them are aged between 27-29 and have completed their $(43.5 \%)$ bachelor degree and rest of them are undergraduates $(24.2 \%)$ and post graduate holders (29\%). Although a significant number of respondents (Figure 6) (64.5\%) are from Asians countries and others are from Europe $(24.2 \%)$, Australian (4.8\%) and American (6.5\%) regions. The majority of female (Figure 4) volunteers are bachelor degree holders and higher numbers of male volunteers hold bachelor degrees and post graduate degrees. 
Table 1

Socio demographic characteristics of the Sample

\begin{tabular}{|c|c|c|}
\hline Variable & Categories & $\%$ \\
\hline & Male & 41.9 \\
\hline Gender & Female & 58.1 \\
\hline \multirow[t]{5}{*}{ Age } & $18-20$ & 0 \\
\hline & $21-23$ & 25.8 \\
\hline & $24-26$ & 34.9 \\
\hline & $27-29$ & 29 \\
\hline & $30+$ & 9.7 \\
\hline \multirow[t]{5}{*}{ Geographical Location } & Asia & 64.5 \\
\hline & Africa & 0 \\
\hline & Europe & 24.2 \\
\hline & Australia & 4.8 \\
\hline & America & 6.5 \\
\hline \multirow[t]{5}{*}{ Education Level } & Higher Secondary & 3.2 \\
\hline & Undergraduate & 24.2 \\
\hline & Graduate & 43.5 \\
\hline & Post Graduate & 29 \\
\hline & Vocational Qualification & 0 \\
\hline
\end{tabular}

Source: Survey Data

\section{Perception of the Impact of Motivational Factors for Volunteerism}

The block of questionnaires were analysed according to sport volunteers' perception of the impact of motivational dimension for participating in sport volunteerism. According to the Bang and Chelladurai's (2003) Volunteer motivation Model researcher prepared 20 items to measure volunteer motivation to participate in sport volunteerism. These items were divided into five sections such as Interpersonal Contacts, Career Orientation, Personal Growth, Community Involvement and Love of Sport. The descriptive data of Table 02 shows the volunteers' degree of agreement regarding their motivation towards sport volunteering. It is interesting to note that the sport volunteers stated that all the factors above are influencing their volunteerism in sport, with a score more than 3 points. Among these motivational factors Love of sport (4.33), Career Orientation (4.19) and Interpersonal Contact (4.16) are the most influential motivational factors encouraging sport volunteerism in sample population.

As regarding the perception of sport volunteers shown in the results (Table 02 and Table 03) all motivational factors influence sport volunteer satisfaction, although most influential factors of sport volunteer satisfaction are Love of Sport, Career Orientation and Interpersonal Contacts. The volunteers are highly influenced to participate in sport volunteering to meet and work with new people according to the sub-items of Interpersonal contact factor. According to the career orientation motivation factor, volunteers are heavily influenced to engage in sport volunteering to get work related practical experience and add something for their personal resume. As for Love of Sport factor, volunteers are most influenced to take part in sport volunteer activities because they enjoy sport activities and love of it. 
Table 02

Degree of agreement with the Motivational Factors of Sport Volunteerism

\begin{tabular}{|c|c|c|c|}
\hline Variables & $\mathrm{N}$ & Mean & Std. Deviation \\
\hline Interpersonal contact & 186 & 4.1613 & 0.87661 \\
\hline Career Orientation & 186 & 4.1903 & 0.90435 \\
\hline Personal Growth & 186 & 3.9758 & 0.94086 \\
\hline Community Involvement & 186 & 3.8884 & 0.94009 \\
\hline Love_of_Sport & 183 & 4.3388 & 0.95214 \\
\hline Valid N (listwise) & 183 & & \\
\hline
\end{tabular}

Source: Survey Data

Table: 03

Degree of agreement of each Items with the Motivational Factors of Sport Volunteerism

\begin{tabular}{|c|c|c|}
\hline Items & Mean & $\begin{array}{l}\text { Std. } \\
\text { Deviation }\end{array}$ \\
\hline \multicolumn{3}{|l|}{ Interpersonal Contacts } \\
\hline I want to interact with others & 4.06 & 1.137 \\
\hline I want to work with different people & 4.26 & 1.064 \\
\hline I want to meet people & 4.23 & 0.96 \\
\hline I want to develop relationships with others & 4.1 & 1.014 \\
\hline \multicolumn{3}{|l|}{ Career Orientation } \\
\hline Volunteering experience will look good on my resume & 4.15 & 1.137 \\
\hline I want to gain some practical experience & 4.24 & 0.998 \\
\hline I can make new contacts that might help my future business or career & 4.1 & 1.061 \\
\hline I want to gain work related experience & 4.31 & 0.98 \\
\hline I want to gain experience that would be beneficial in any future job & 4.16 & 1.098 \\
\hline \multicolumn{3}{|l|}{ Personal Growth } \\
\hline Volunteering makes me feel needed & 3.9 & 1.106 \\
\hline I can explore my own strength & 4.1 & 0.931 \\
\hline Volunteering makes me feel important & 3.92 & 1.129 \\
\hline Volunteering allows me to gain a new perspective on things & 3.98 & 1.058 \\
\hline \multicolumn{3}{|l|}{ Community Involvement } \\
\hline I enjoy volunteering because of my devotion to my organization & 3.9 & 1.046 \\
\hline Hosting some sport events raises the prestige of my organisation or country & 3.92 & 0.961 \\
\hline My love for my university makes me help it run great events & 3.76 & 1.163 \\
\hline I want to express my pride in my organisation or country & 3.97 & 1.08 \\
\hline \multicolumn{3}{|l|}{ Love of Sport } \\
\hline I enjoy being involved in sport activities & 4.39 & 1.032 \\
\hline I like any event related to sports & 4.26 & 1.018 \\
\hline Sport is something I love & 4.39 & 0.976 \\
\hline
\end{tabular}

Source: Survey Data 
Table 04

Perception of Impact of the Satisfaction Dimension for Sport Volunteerism

\begin{tabular}{|c|c|c|c|}
\hline & $\mathrm{N}$ & Mean & Std. Deviation \\
\hline Organisation support & 186 & 3.773 & 0.84917 \\
\hline Empowerment & 186 & 4 & 0.83643 \\
\hline Group Integration & 186 & 3.8427 & 0.89846 \\
\hline Valid N (listwise) & 186 & & \\
\hline
\end{tabular}

Source: Survey Data

The set of questions were analysed the understanding of Sport volunteers' perception on the impact of Satisfaction dimensions. That consisted of 20 items divided into three sections such as Organisational Support, Group Integration and Empowerment. The descriptive results (Table 03 and 04) show that the volunteers are satisfied with their Satisfaction dimensions, with a score of more than 3.0 points. These are questions particularly designed to understand the volunteer satisfaction regarding support and opportunity provided by volunteer organisations during the volunteer program. Empowerment (4.0) and Group Integration (3.8) were the most satisfied factors among these satisfaction dimensions.

According to the perception of volunteers about Empowerment of their volunteer program, degree of agreement is generally higher and in many cases higher than the mean which is 3 points. Higher average degrees of agreement were found in relation to provision of opportunity to empowerments with a score of more than 4 points, in terms of providing opportunity to learn new things, assigning jobs that fit their skills, give chance to utilize their knowledge and skills and make them realise their capabilities (Table 04). In addition, Group integration is the second highest averaged (3.8) factor among the Satisfaction Dimension which perceive that volunteer programmes provide the opportunity for volunteers to socialize with others and volunteers are satisfied with their personal experience regarding socialising with other volunteers. Furthermore, volunteers have rated their satisfaction about the support of their volunteer organisations. In general, the results show (Table 04 and 05) the average satisfaction of organisation support higher than 3 points. As per the results, volunteers are satisfied with the support they receive from the organisations. Especially, with regards to the Organisational support, volunteers are most satisfied (Table 05) with the support from the staff of organisations (4.0), rewards awarded by the organisation (3.8), appropriateness of the organisation work (3.8), support network related to volunteer problems (3.7) and autonomy (3.7). 
Table 05

Degree of agreement of each Item with the Satisfaction Dimension of Sport Volunteerism

\begin{tabular}{|c|c|c|c|}
\hline Variables & $\mathrm{N}$ & $\begin{array}{l}\text { Mea } \\
\mathrm{n}\end{array}$ & $\begin{array}{l}\text { Std. } \\
\text { Deviation }\end{array}$ \\
\hline \multicolumn{4}{|l|}{ Group Integration } \\
\hline \multirow{3}{*}{ My relationship with other volunteers in the organisation } & 18 & & \\
\hline & 6 & 3.92 & 0.975 \\
\hline & 18 & & \\
\hline \multirow{4}{*}{$\begin{array}{l}\text { The friendships I have made while volunteering here } \\
\text { The amount of interaction I have with other volunteers in the } \\
\text { organisation }\end{array}$} & 6 & 4.03 & 1.002 \\
\hline & 18 & & \\
\hline & 6 & 3.76 & 0.998 \\
\hline & 18 & & \\
\hline The amount of time spent with other volunteers & 6 & 3.66 & 1.166 \\
\hline \multicolumn{4}{|l|}{ Empowerment } \\
\hline \multirow{3}{*}{ The opportunity I have to learn new things } & 18 & & \\
\hline & 6 & 4.21 & 1.021 \\
\hline & 18 & & \\
\hline \multirow[t]{2}{*}{ The fit of the volunteer work to my skills } & 6 & 4.11 & 0.955 \\
\hline & 18 & & \\
\hline \multirow{6}{*}{$\begin{array}{l}\text { How worthwhile my contribution is } \\
\text { The amount of effort I put in as equalling the amount of chance I } \\
\text { influence } \\
\text { The chance I have to utilize my knowledge and skills in my volunteer } \\
\text { work }\end{array}$} & 6 & 4.1 & 0.858 \\
\hline & 18 & & \\
\hline & 6 & 3.89 & 0.955 \\
\hline & 18 & & \\
\hline & 6 & 4.02 & 1.011 \\
\hline & 18 & & \\
\hline \multirow{3}{*}{$\begin{array}{l}\text { The access I have to information concerning the organisation } \\
\text { The freedom I have in deciding how to carry out my volunteer } \\
\text { assignment }\end{array}$} & 6 & 3.79 & 1.037 \\
\hline & 18 & & \\
\hline & 6 & 3.89 & 0.972 \\
\hline \multicolumn{4}{|l|}{ Organisation Support } \\
\hline \multirow{3}{*}{$\begin{array}{l}\text { The support network that is in place for me when I have volunteer related } \\
\text { problems }\end{array}$} & 18 & & \\
\hline & 6 & 3.71 & 1.116 \\
\hline & 18 & & \\
\hline \multirow{4}{*}{$\begin{array}{l}\text { The way in which the agency provides me with performance feedback } \\
\text { The flow of communication coming to me from paid staff and volunteer } \\
\text { manager }\end{array}$} & 6 & 3.73 & 1.053 \\
\hline & 18 & & \\
\hline & 6 & 3.6 & 1.087 \\
\hline & 18 & & \\
\hline \multirow[t]{2}{*}{ The support I receive from people in the organisation } & 6 & 4.06 & 1.001 \\
\hline & 18 & & \\
\hline \multirow[t]{2}{*}{ The amount of information I receive about what the organisation is doing } & 6 & 3.66 & 0.985 \\
\hline & 18 & & \\
\hline How often the organisation acknowledge the work I do & 6 & 3.88 & 0.992 \\
\hline \multirow{3}{*}{$\begin{array}{l}\text { The amount of permission I need to get to do the things I need to do on } \\
\text { this job }\end{array}$} & 18 & & \\
\hline & 6 & 3.74 & 1.002 \\
\hline & 18 & & \\
\hline \multirow{4}{*}{$\begin{array}{l}\text { The degree of cohesiveness I experience with the organisation } \\
\text { The degree to which the organisation communicates its goals and objectives } \\
\text { to volunteers. }\end{array}$} & 6 & 3.81 & 0.95 \\
\hline & 18 & & \\
\hline & 6 & 3.77 & 0.977 \\
\hline & 18 & & \\
\hline Valid N (listwise) & 6 & & \\
\hline
\end{tabular}

Source: Survey Data 
Table 06

Perception on Overall Satisfaction of Volunteer Experience

\begin{tabular}{|c|c|c|c|}
\hline Variables & $\mathrm{N}$ & Mean & Std. Deviation \\
\hline Overall Satisfaction & 186 & 4.2097 & 0.86625 \\
\hline Valid N (listwise) & 186 & & \\
\hline
\end{tabular}

Source: Survey Data

The questionnaire has created in a separate section with the purpose of evaluating

Volunteer's overall satisfaction in relation to their experience. That section has consisted of two items to measure the overall satisfaction of the volunteers. According to the results of Table06 Average of volunteer satisfaction is higher than 4 points. It is interesting to note that the volunteers have positive experience and are very satisfied (4.2) about their volunteer Program.

\section{The Impact of Motivation and Satisfaction Dimensions to Volunteer Overall Satisfaction}

Multiple recreation analysis was used to predict the satisfaction level of volunteer experience based on volunteer Motivation in order to examine the contribution of variables towards the predictions of Volunteer Satisfaction. According to the Bang \& Chelladurai (2003) Volunteer Motivation Scale, the five Motivation dimensions such as Interpersonal Contact, Personal Growth, Community Involvement and Love of Sport were added into multiple regression equation with overall Satisfaction as the dependent variable. The full model equation was based on linear combinations of the five variables, the model was significant $(\mathrm{f}(18.740)=9.59, \mathrm{p}=$ .000 ), and $32 \%$ of the variability (Adjusted R Square .328).Volunteer Satisfaction was attributed to variability in the volunteer motivations (See Appendix 01). However according to the coefficients results all the variable were not significant. However, multiple regression analysis coefficients Table shows the relationship between independent and dependent variables, that results show only two independent variables such as Career orientation and Personal Growth $(\mathrm{B}=-.19, \mathrm{~T}=-2.10, \mathrm{p}=.037$ and $\mathrm{B}=.674, \mathrm{~T}=5.91, \mathrm{p}=.000)$ have influenced volunteer satisfaction (See Appendix 01). Therefore, Personal Growth and Career orientation are the best sub set of independent variables that explain and predict volunteer satisfaction and also these two Motivation factors are heavily influencing variables towards volunteer satisfaction.

The proposed volunteer satisfaction dimension model was constructed based on Kuhn and Guzley's (2002) Volunteer Satisfaction index. Multiple regression analysis was used to predict the satisfaction level of volunteer experience based on their volunteer program for the purpose of explaining the research objective two. Group Integration, Empowerment and Organisation Support were added into Liner Multiple Regression equation with overall volunteer satisfaction as the dependent variable. The model was significant $(\mathrm{F}(107.612)=29.61, \mathrm{p}$ $=.000$ ) and $63 \%$ of the variability in volunteer satisfaction was determinable to variability in the volunteer experience regarding their volunteer program (Adjusted $\mathrm{R}^{2}=.634$ ) (See Appendix 01). Only two variables such as Empowerment $(B=.551, T=5.870, p=.000$ and Organisation Support $(B=.295, T=3.811, p=.000)$ were significant among the three independent Variables that predict the volunteer satisfaction. Therefore, Empowerment and Organisation support of the volunteer programs have heavily influenced Volunteer Satisfaction (See Appendix 01).

\section{Discussion}

The results of current study present a number of areas for discussion, even though these areas were discussed in some of the previous researches on volunteer Satisfaction and Motivation and some unique aspects were revealed as well. In addition, it sheds light on the Volunteer Satisfaction and Motivation of sport volunteers as well as it would help the sport volunteer organisations to understand volunteer behaviour and their Motivation and Satisfaction principles for volunteering in sport.

\section{Volunteer Perception of Motivate to Sport Volunteerism}

The current study identifies aspect of the volunteer experience that enhances satisfaction and motivation. Consistent with the previous researches, the present study showed evidence in volunteer motivation (Clary et al., 1998; Johnston et al., (1999). Function approach theory noted that the purpose of people working as volunteers was to satisfy their personal needs and wishes or to gain an opportunity to reach their personal goals with volunteerism (Clary et al., 1992). In addition, Self-determination theory reports that people are basically motivated to participate in a sport volunteering that might cause intrinsic and extrinsic motives such as interest of game, enjoyment of helping others, gaining free entry and souvenirs. Notably, the volunteers are motivated to participate 
in volunteering in sport are influenced by several factors such as Interpersonal contact, Career Orientation, Personal Growth, Community Involvement and Love of Sport. Those factors are considerably influencing sport volunteerism. Supporting to these findings Farrell et al. (1999) noted that interpersonal contact corresponds with the sport volunteer motivation. In addition, Clary et al. (1998) noted that Personal growth is enhancing the volunteers' motivation for participating in sport volunteerism. Furthermore, career orientation is also congruent to the volunteer motivation (Clary et al., 1998). The evidence seems to be strong according to the Social Adjective Function; the work of Smith et al. (1956) asserted that volunteers are involved in volunteering with the intention of helping others. As well as career is another function that is granted to volunteers concerned with career orientated benefits that can be obtained from participating in volunteer activities. Thus, the utilitarian function studied by Katz (1960) is related to career function, study by Jenner (1982) asserted that the volunteers in junior league perceive that volunteering as a process of preparing for careers or maintaining the career relevant skills. Some research reported that people do volunteerism to help, maintain or to enhance a positive perception from others while other evidence show that people do volunteerism for the reasons of personal development and selfesteem (Anderson \& Moore, 1978; Jenner, 1982).

\section{Volunteer Perception of Motivational Categories to Participating Volunteerism}

The present study found that volunteers are motivated to participate in sport volunteerism to build-up new relationships, work with different people and to meet and expand their personal contacts. Thus volunteers engage in sport volunteerism for the purpose of developing their future businesses or career contacts as well as to gain practical experience and add some valuable professional experience to their resume. Self-determination theory asserted that some volunteers involved in volunteering actions concerning sport in administrative terms. Therefore they enjoy volunteering more than leisure which is related to self-determination and extrinsic motives (Cuskelly \& Harrington, 1997) as well as SDT identified that challenging activities, sense of care, respect and relationship with others in the social environment are some other factors motivating volunteerism (Gagne \& Deci, 2005). It is interesting to note that the current study found volunteers are highly motivated for volunteerism because of the new relationships they build with other people. In addition, Social function theory suggested that volunteering may reflect the motivation concerning a relationship with others which provide opportunities to individuals to be with others and to be engaged in activities with their favourite people (Gagne \& Deci, 2005).

Furthermore, Bang \& Ross (2009) discovered that the Love of Sport factor was found to be a strong motivational factor among event motivation, which is the main reason for volunteering converging on the sport itself rather than for the simple reason of helping others. The results of current study are similar to sport event volunteering motivational causes, it means that people are focused on fulfilling their own desires of sport related volunteerism and they will often volunteer for sport events and sport organisations regardless of size. The community involvement is another factor that motivates people for sport volunteering. Matsuoka and Chelladurai (2006) indicated sport teams or events connected with regions or city. It is the primary motivation of the volunteers to support and facilitate the success of the events hosted by the communities. However, present study results show community involvement is not a considerable motivational factor to be involved in sport volunteerism comparing with other variables. This finding is particularly valuable for any volunteer program of any scale and it is important for sport managers when recruiting and retaining volunteers.

\section{Volunteer perception on level of Satisfaction regarding volunteer programme with their experience.}

The present study also analysed the influence of satisfaction dimension towards volunteer satisfaction. The satisfaction dimensions are contained within the volunteers' volunteer organisation and program. GalindoKuhn and Guzley's (2002) Volunteer Satisfaction Index was used for the present study. The results of each three dimensions (Organisation Support, Group Integration and Empowerment) show perception of volunteers' level of satisfaction with their experience regarding volunteer program and organisation. The volunteer satisfaction factors are positively influencing volunteer satisfaction. The current study sample population's volunteer programmes are well planned and managed because volunteers are satisfied about their volunteer programs which defines that the managers provide what they expect which is represented in each variable mean values.

Group integration is emerged in this study as considerable factor to explain volunteer satisfaction. As defined earlier in the methodology, group integration represents the relationships that volunteers develop with other volunteer and paid staff. As results of this study volunteers have significant opportunities to be socialised with other volunteers. However, Social Exchange Theory explained that people volunteering to build relationships with each other comparing costs and rewards in an organisation, when these benefits are perceived much greater than the cost, individuals relate more and develop a deeper relationship with the person or organisation (Bang \& Ross, 2009). According to Social Exchange theory, present study evaluated the perception of empowerment in an individual's volunteer program. Under the satisfaction factor of empowerment was measured the opportunities provided by particular volunteer organisation to volunteers for the purpose of learning new things, finding work 
suitable for skills and providing opportunities for the amount of effort. The results show that perceptions of volunteers regarding each of these sub categories were satisfied. It can be concluded that the volunteer experience of empowerment in their volunteer program positively influence their satisfaction as well as an individual's volunteer program was designed to enhance volunteer job related skills. Wong et al. (2010) study was presented as support of the above findings; the study was done by using VSI in Chinese population, the results show that volunteers are more focused on gaining personal benefits from volunteering such as the feeling of empowerment and to obtain the organisation's support.

The organisation support is another important satisfaction measurement factor in Volunteer Satisfaction Index. According to the current study results, it is interesting to note that volunteers' perception of organisation support is satisfied. The organisation support factor covers several areas of organisation support such as communication between volunteers and staff, support network for problem solving, performance feed-back, autonomy and communication of organisation goals. All these sub categories reflect the amount of support volunteers receive from their organisation. All the organisational supports sub categories are satisfied. It can be concluded that an individual's volunteer program has positive organisation support. Thus volunteers are most satisfied about the support received from the staff of organisations and also other sub factors such as autonomy, communication, feed-back and problem solving of organisation support are above the average level of satisfaction. Silverberg et al. (2001) noted that sense of satisfaction of work is a vital component of the volunteer job satisfaction such as relationships with cCo-workers, quality of supervision, quality of communication and effective supervision. Thus, STD approach reveals managerial support for employees' autonomy which is connected with the satisfaction of needs for autonomy (Gagne \& Deci, 2005). Furthermore, Pauline (2011) claims that both direct and indirect extensive amount of communication within voluntary associations that would lead towards great levels of commitment by volunteers and the lower detachment from the organisations. Especially face to face communication was of greater aid to volunteers in their satisfaction (Byren, 2006). The results of the current study supported the explanation of Self-determination theory; the results indicated that volunteers expect certain amount of autonomy to do their assigned work. In addition, Allen \& Shaw (2009) suggested that accurate perception would make them value their services in sport volunteering, to let them self-determine their performance rather than motivate them to gain rewards and avoid disapproval of the managers. However, Pauline (2011) and Rice \& Fallon (2011) do not support Allen \& Shaw's (2009) argument that explained volunteer satisfaction relevant to Social Exchange Theory, they noted in their studies that the rewards program of volunteer programs may also have positively influenced volunteer perception urging sport volunteerism because rewards would make them to appreciate their volunteer work.

\section{What Motivation Factors best explain the Volunteer Satisfaction}

In addition, the present study formulated multiple regression analysis to predict the volunteer satisfaction level of experience based on volunteer motivation (see appendix 01). The results indicated that the two motivation factors (Personal Growth and Career orientation) best explain the level of respondents' satisfaction with their volunteer experience. The similar study of Bang \& Ross (2009) found that there are three motivation factors such as Expression of values, career orientation and Love of sport that best explained the volunteer satisfaction with their volunteer experience. Although present study found only two motivation factors which best explain volunteers' level of satisfaction and also only one factor (Career Orientation) has cooperated with Bang \& Ross (2009) study of volunteer motivation and satisfaction in 2004 Twin Cities Marathon. However, Clary \& Snyder (1999) designed a volunteer function inventory by including six factors and finally concluded on what motivation would support the actions of the volunteer in the actual situation. It was concluded that it does not solely depend on the person or on the situation but rather depend on interaction of person involved and the dynamic and situational opportunities.

\section{Overall satisfaction of Volunteers}

Finally, current study investigated perception of overall satisfaction with individuals' volunteer experience. The results indicated that the overall satisfaction is considerably higher than the average point of satisfaction (see table 06). It is interesting to note that most of individual volunteers have positive experience in their volunteer programmes. The results reflect another angle of the findings which show the content of individuals' volunteer program from which it can be concluded most of volunteers had an opportunity to participate well planned and managed volunteer programmes. 


\section{Conclusion}

The study aimed to investigate characteristics of volunteer motivation and factors responsible for the volunteer satisfaction by using Bang \& Challadurai's (2003) volunteer motivation scale and Kuhn \& Guzley's (2002) volunteer satisfaction index. These two pre validated models were used to provide a better theoretical background for the present study. The current research used both Volunteer Motivation Scale and Volunteer Satisfaction Index to measure how these characteristics contributed towards volunteer satisfaction.

From diverse key themes several motivation factors were determined such as personal growth, interpersonal contact, career orientation, community involvement and love of Sport to have an impact on motivation for sport volunteerism. As per the results, volunteer satisfaction dimensions have significant impact towards sport volunteers' satisfaction. Basically, volunteers have allocated their time and effort for a wide variety of reasons. In the past studies, understanding volunteer motivations have been based on theories of altruism and selflessness (Rehberg, 2005); accordingly primary motivation of volunteering is the urge to help others. However, other motives should be taken into account in understanding volunteers and utilizing them for effective management practices (Bang \& Ross, 2009). Therefore, this study investigated other motivation factors such as social contacts, career oriented, emotional needs, personal interest etc. rather than altruism motives. Basically all the factors including Volunteer Motivation Scale have an impact on volunteer satisfaction according to the perception of volunteer experience. In addition, Personal Growth and Career orientation have significant impact towards volunteer satisfaction. It can be concluded the factors that influence an individual's benefits have a major impact on participating in sport volunteerism and reaching personal desires through volunteerism leads to grater satisfaction. A study done by Finkelstein (2007) noted that satisfaction depends on the volunteer experience fulfilling the extent of volunteers' goals. Similarly, Silverberg et al. (2001) supported argument of Finkelstein (2007) and found in their study of park and recreation volunteers' satisfaction are based on both job environment and psychological needs met by volunteering. The results of present study reveals that satisfaction dimensions such as Organisation support, Empowerment and Group integration have significant influence on volunteer satisfaction as well. The empowerment and Organisation Support factors have a significant influence to predict volunteer satisfaction. It can be interpreted that positive organisation support (providing new knowledge, providing opportunities to develop personal abilities, amount of welfare facilities provided and performance evaluation) and empowerment through volunteer programmes (provide chance to test their knowledge, amount of autonomy, and space of accessing data) lead to greater volunteer satisfaction. All these satisfaction dimensions are focused to receive volunteer perception of what the volunteers expect from volunteer organisations to satisfy themselves. In conclusion, all results gained from the volunteers in present study for both models of motivation and satisfaction are very likely focus on satisfying their personal goals through participating in sport volunteerism.

\section{References}

Adams, C. H., \& Shepherd, G. J. (1996). Managing volunteer performance: Face support and situational features as predictors of volunteers' evaluation of regulative messages. Management Communication Quarterly, 9, 363-388.

Allen, J.B., \& Shaw, S. (2009). "Everyone rolls up their sleeves and mucks in”: Exploring volunteers' motivation and experiences of the motivational climate of a sporting event. Sport Management Review, 12(2), 79-90.

Andersen, D.P.S. (2011). Research Methods and Design in Sport Management. Champaign: Human Kinetics.

Anderson, J. C., \& Moore, L. (1978). The motivation to volunteer. Journal of Voluntary Action Research, 7, 5160.

Armstrong, M., \& Taylor, S. (2014). Armstrong's handbook of human resource management practice (13 ${ }^{\text {th }}$ ed.). London: Kogan Pag

Baker, T.L. (1994). Doing Social Research (2 ${ }^{\text {nd }}$ ed.), New York: McGraw-Hill Inc.

Balzer, w.k., Smith, P. C., Kravitz, D.A., Lovell. S.E., Paul, K.B., Reilly, B.A \& Reilly, C.E. (1990). User's manual for the Job Descriptive Index (JDI) and the Job in General (JIG) Scales. Bowling Green, OH: Bowling Green State University.

Bang, H. \& Chelladurai, P. (2003). Motivation and Satisfaction in Volunteering for 2002 World Cup in Korea. Paper presented at the Conference of the North American Society for Sport Management, Ithaca, New York.

Bang, H., \& Ross, S.D. (2009). Volunteer motivation and satisfaction. Journal of Venue and Event Management, $1(1), 61-77$. 
Bang, H., Alexandris, K. \& Ross, S.D. (2008). Validation of the revised volunteer motivations scale for international sporting events (VMS-ISE) at the Athens 2004 Olympic Games. Event Management, 12(3-4), 119-131.

Bang, H., Ross, S., \& Reio Jr, T.G. (2012). From motivation to organizational commitment of volunteers in nonprofit sport organizations: The role of job satisfaction. Journal of Management Development, 32(1), 96-112.

Bassett, C., \& Bassett, J. (2003). Quantitative and qualitative research. The Journal of Perioperative Practice, 13(3), 116.

Ben-Zur, H., \& Yagil, D. (2005) The relationship between empowerment, aggressive behaviours of customers, coping, and burnout. European Journal of Work and organizational Psychology, 14(1), 81-99.

Bjerneld, M., Lindmark, G., McSpadden, L.A.. \& Garrett, M.J. (2006). Motivations, concerns, and expectations of Scandinavian health professionals volunteering for humanitarian assignments. Disaster Management \& Response, 4(2), 49-58.

Boezeman, E.J., \& Ellemers, N. (2007). Volunteering for charity: pride, respect, and the commitment of volunteers. Journal of Applied Psychology, 92(3), 771.

Brown, E. (1999). 'The Scope of Volunteer Activity and Public Service', Law and Contemporary Problems, 62(4), 17-42.

Bruin, J. (2011). SPSS FAQ: What does Cronbach's alpha mean? Retrieved from http://www.ats.ucla.edu/stat/spss/faq/alpha.html

Bussell, H., \& Forbes, D. (2001). 'Understanding the Volunteer Market: The What, Where, Who and Why of Volunteering'. International Journal of Nonprofit and Voluntary Sector Marketing, 7 (3), 244-57.

Byren, L. (2006). Bounce-back of episodic volunteers in local government community environmental groups (LGCEG). Proceedings of the 11th National Conference on Volunteering, Volunteering Australia, Melbourne.

Cantor, N. (1994). Life task problem solving: Situational affordances and personal needs. Personality and Social Psychology Bulletin, 20, 235-243.

Carla A.Costa, Laurence Chalip, B. C. G. (2006). Reconsidering the Role of Trining in Event Volunteers' Satisfaction. Sport Management Review, 9, 165-182

Carr, L. T. (1994) The strengths and weaknesses of quantitative and qualitative research: what method for nursing? Journal of advanced nursing, 20 (4), 716-721.

Chelladurai, P. (1999). Management of Human Resources in Sport and Recreation. Champaign, IL: Human Kinetics Publishers.

Chelladurai, P. (2006). Human resource management in sport and recreation (2 ${ }^{\text {nd }}$ ed.). Champaign: Human Kinetics.

Chelladurai, P., \& Madella, A. (2006b), Human resource management in Olympic sport organizations. Leeds: Human Kinetics.

Cheung, F.Y.L., Tang, C.S.K. \& Yan, E.C.W. (2006). A Study of Older Chinese in Hong Kong: Factors Influencing Intention to Continue Volunteering. Journal of Social Service Research, 32(4),193-209.

Clary, E.G. (2004). Volunteer Sustainability: How non-profits can sustain volunteers' commitment. Snapshots: Research Highlights from the Non-profit Sector Research Fund, 36, 1-6.

Clary, E.G., \& Miller, J. (1986). Socialization and situational influences on sustained altruism. Child development, 1358-1369.

Clary, E.G. \& Orenstein, L. (1991). The amount and effectiveness of help: The relationship of motives and abilities to helping behaviour. Personality and Social Psychology Bulletin, 17(1), 58-64.

Clary, E.G., \& Snyder, M. (1999) The motivations to volunteer theoretical and practical considerations. Current directions in psychological science, $8(5), 156-159$.

Clary, E.G., Snyder, M., \& Ridge, R. (1992) Volunteers' motivations: A functional strategy for the recruitment, placement, and retention of volunteers. Non-profit Management and Leadership, 2(4), 333-350.

Clary, E.G., Snyder, M., Ridge, R.D., Copeland, J., Stukas, A.A., Haugen, J. \& Miene, P. (1998). Understanding and assessing the motivations of volunteers: a functional approach. Journal of personality and social psychology, 74(6), 1516.

Cnaan, R., Handy, F., \& Wadsworth, M. (1996). 'Defining who is a Volunteer: Conceptual and Empirical Considerations', Nonprofit and Voluntary Action Quarterly, 25(3), 364-83.

Cnaan, R.A., \& Goldberg-Glen, R.S. (1991). Measuring motivation to volunteer in human services. The journal of applied behavioral science, 27(3), 269-284. 
Colakoglu, U., Culha, O. \& Atay, H. (2010). The Effects of Perceived Organisational Support on Employees 'affective outcomes: evidence from the hotel industry. Tourism and hospitality management, 16(2), $125-150$

Cole, G.A. (1992). Management Theory and Practice ( $4^{\text {th }}$ ed.). Cengage Learning EMEA.

Costa, C.A., Chalip, L., Green, B.C. \& Simes, C. (2006). Reconsidering the role of training in event volunteers' satisfaction. Sport Manosagement Review, 9(2), 165-182.

Cravens, J. (2006). Involving international online volunteers: Factors for success, organizational benefits, and new views of community. The International journal of volunteer administration, 24(1), 15-23.

Creswell, J.W. (1998). Qualitative Inquiry and Research Design: Choosing Among Five Traditions. California: SAGE publications.

Cuskelly, G., \& Boag, A. (2001). Organisational commitment as a predictor of committee member turnover among volunteer sport administrators: results of a time-lagged study. Sport Management Review, 4(1), 65-86.

Cuskelly, G., \& Harrington, M. (1997). Volunteers and leisure: Evidence of marginal and career volunteerism in sport. World Leisure \& Recreation, 39(3), 11-18.

Cuskelly, G., Hoye, R. \& Auld, C. (2006). Working with volunteers in sport: Theory and practice. Routledge.

De Miguel, E., Iribarren, I., Chacon, E., Ordonez, A. \& Charlesworth, S. (2007). Risk-based evaluation of the exposure of children to trace elements in playgrounds in Madrid (Spain). Chemosphere, 66(3),505513.

Deci, E. L., \& Ryan, R. M. (1985). Intrinsic motivation and self-determination in human behaviour. New York: Plenum.

Deci, E.L., \& Ryan, R.M. (2000). The" what" and" why" of goal pursuits: Human needs and the selfdetermination of behavior. Psychological inquiry, 11(4), 227-268.

Deci, E.L., \& Ryan, R.M. (2002). Handbook of self-determination research. University Rochester Press.

Deci, E.L., \& Ryan, R.M. (2008). Self-determination theory: A macro-theory of human motivation, development, and health. Canadian psychologie/Psychologie canadienne, 49(3), 182.

Doherty, A. (2009). The volunteer legacy of a major sport event. Journal of Policy Research in Tourism, Leisure and Events, 1(3), 185-207.

Doherty, A.J. (1998). Managing our human resources: A review of organisational behaviour in sport. Sport Management Review, 1(1), 1-24.

Du, M. (2009). Job Satisfaction among Volunteers of the 2007 Special Olympics World Summer Games. Asian Journal of Physical Education \& Recreation, 15(2).

Dworkin, G. (1988). The theory and practice of autonomy. New York: Cambridge University Press.

Eisenberger, R., Stinglhamber, F., Vandenberghe, C. Sucharski, I.L. \& Rhoades, L. (2002). "Perceived supervisor support: Contributions to perceived organizational support and employee retention". Journal of Applied Psychology, 87 (3), 565-573.

Fairley, S., Kellett, P. \& Green, B.C. (2007). Volunteering abroad: Motives for travel to volunteer at the Athens Olympic Games. Journal of Sport Management, 21(1), 41.

Farmer, S.M., \& Fedor, D.B. (1999). Volunteer participation and withdrawal. Non-profit Management and Leadership, 9(4), 349-368.

Farrell, J.M., Johnston, M.E., \& Twynam, G.D. (1998). "Volunteer motivation, satisfaction, and management at an elite sporting competition", Journal of Sport Management, 12(4), 288-300.

Feldman, M.S. (2000). Organizational routines as a source of continuous change. Organization science, 11(6), 611-629.

Field, D., \& Johnson, I. (1993). Satisfaction and change: A survey of volunteers in a hospice organisation. Social Science Medicine, 36,1625-1633.

Finkelstein, M. A., \& McIntyre, S. (2005). A social psychological perspective on recruitment and retention of hospice volunteers. Journal of Volunteer Administration, 23, 6-10.

Finkelstein, M.A. (2007). Correlates of satisfaction in older volunteers: A motivational perspective. The International Journal of Volunteer Administration, 24(5), 6-12.

Freeman, R. (1997). 'Working for Nothing: The Supply of Volunteer Labour'. Journal of Labour Economics, 15 (1), 140-166.

Frisch, M. B., \& Gerard, M. (1981). Natural helping systems: A survey of Red Cross volunteers. American Journal of Community Psychology, 9, 567-579.

Gagné, M., \& Deci, E.L. (2005). Self-determination theory and work motivation. Journal of Organizational behavior, 26(4), 331-362. 
Galindo-Kuhn, R., \& Guzley, R.M. (2002). The volunteer satisfaction index: Construct definition, measurement, development, and validation. Journal of Social Service Research, 28(1), 45-68.

Gidron, B. (1978). Volunteer work and its rewards. Volunteer Administration, 11(3), 18-32.

Grammatikopoulos, V., Koustelios, A., \& Tsigilis, N. (2006). Construct validity of the special event volunteer motivation scale for Greek volunteers.Leisure/Loisir, 30(1), 287-305.

Green, B.C., \& Chalip, L. (1998). Sport tourism as the celebration of subculture. Annals of Tourism Research, 25(2), 275-291.

Hannagan, T.(1995). The Challenge of Management. Hannagan, T. \& contributors, Management, Concepts \& Practices, Pitman Publishing, London, 3-36.

Hannagan, T. (1995). Management Concept and Practices. Pearson Education.

Hodgkinson, V. (2003). 'Volunteering in Global Perspective', in Dekker, P., \& Halman, L. (eds.), The Values of Volunteering, Cross-Cultural Perspectives, (New York: Kluwer Academic/Plenum Publishers), 35-53.

Hollembeak, J., \& Amorose, A.J. (2005). Perceived coaching behaviors and college athletes' intrinsic motivation: A test of self-determination theory. Journal of applied sport psychology, 17(1), 20-36.

Hoy, W.K., \& Miskel, C.G. (1987). Educational administration: Theory, research, and practice. Random House Trade.

Jenner, J.R. (1982). Participation, leadership, and the role of volunteerism among selected women volunteers. Journal of Voluntary Action Research.

Johnson, R. B., \& Onwuegbuzie, A. J. (2004). Mixed methods research: A research paradigm whose time has come. Educational researcher, 33(7), 14-26.

Johnston, M.E., Twynam, G.D., \& Farrell, J.M. (1999). Motivation and satisfaction of event volunteers for a major youth organization. Leisure/Loisir, 24(1-2),161-177.

Katz, D. (1960). The functional approach to the study of attitudes. Public opinion quarterly, 24(2), 163-204.

Kemp, S. (2002). The hidden workforce: volunteers' learning in the Olympics. Journal of European Industrial Training, 26(2/3/4), 109-116.

Khasawneh, S. (2011). Human capital planning in higher education institutions: A strategic human resource development. International Journal of Educational Management, 25(6), 534-544.

Larocque, L., Gravelle, F., \& Karlis, G. (2002). Volunteerism and serious leisure: The case of the Francophone Games [Abstract]. Proceedings of the 10th Canadian Congress on Leisure Research, 85-87.

Lavelle, J.J. (2010) "What motivâtes OCB? Insights from the volunteerism literature". Journal of Organizational Behaviour, 31 (6), 918-23.

London 2012 Facts and Figures. (2012). Retrieved from https://stillmed.olympic.org/Documents/Reference_documents_Factsheets/London_2012_Facts_and_F igures-eng.pdf.

Matzler, K., Fuchs, M., \& Schubert, A. (2004). Employee satisfaction: does Kano's model apply? Total Quality Management and Business Excellence, 15(9-10), 1179-1198.

Netting, F.E., Nelson Jr, H.W., Borders, K., \& Huber, R. (2004). Volunteer and paid staff relationships: Implications for social work administration. Administration in Social Work, 28(3-4), 69-89.

Nichols, G., Hogg, E., \& Storr, R. (2016). Motivation of Sport Volunteer in England: A review for Sport England. Retrieved from https://www.sportengland.org/media/10205/motivations-of-sportvolunteers.pdf.

Omoto, A., Snyder, M., \& Martino, S. (2000). 'Volunteerism and the Life Course: Investigating Age-Related Agendas for Action', Basic and Applied Social Psychology, 22(3), 181-97.

Patall, E.A., Cooper, H., \& Robinson, J.C. (2008). The effects of choice on intrinsic motivation and related outcomes: a meta-analysis of research findings. Psychological bulletin, 134(2), 270.

Pauline, G. (2011). Volunteer satisfaction and intent to remain: An analysis of contributing factors among professional golf event volunteers. International Journal of Event Management Research, 6(1).

Pauline, G., \& Pauline, J.S. (2009). Volunteer motivation and demographic influences at a professional tennis event. Team Performance Management: An International Journal, 15(3/4), 172-184.

Phillips, M. (1982). Motivation and expectation in successful volunteerism. Journal of Voluntary Action Research, 11 (1/2), 118-125.

Polit, D.F., Beck, C.T., \& Hungler, B.P. (2001). Essentials of Nursing Research: Methods, Appraisal and Utilization( $5^{\text {th }}$ ed.). Philadelphia: Lippincott Williams \& Wilkins.

Preston, J.B., \& Brown, W.A. (2004). Commitment and performance of non-profit board members. Non-profit Management and Leadership, 15(2), 221-238.

Reeser, J.C., Berg, R.L., Rhea, D., \& Willick, S. (2005). Motivation and satisfaction among polyclinic volunteers 
at the 2002 Winter Olympic and Paralympic Games. British journal of sports medicine, 39(4), 20-20.

Reeser, J.C., Berg, R.L., Rhea, D., \& Willick, S. (2005). Motivation and satisfaction among polyclinic volunteers at the 2002 Winter Olympic and Paralympic Games. British journal of sports medicine, 39(4), 20-20.

Rehberg, W. (2005). Altruistic individualists: Motivations for international volunteering among young adults in Switzerland. Voluntas: International Journal of Voluntary and Non-profit Organizations, 16(2),109122.

Reinboth, M., \& Duda, J.L. (2006). Perceived motivational climate, need satisfaction and indices of well-being in team sports: A longitudinal perspective. Psychology of Sport and Exercise, 7(3),269-286.

Reinboth, M., Duda, J.L., \& Ntoumanis, N. (2004). Dimensions of coaching behavior, need satisfaction, and the psychological and physical welfare of young athletes. Motivation and emotion, 28(3), 297-313.

Rice, R.W., Mcfarlin, D.B., \& Bennett, D.E. (1989). Standers of comparison and job satisfaction. Journal of Applied Psychology, 74, 591-598.

Rice, S. M., \& D, B. J. F. P. (2011). Factors Promoting Perceived Organizational Care: Implication for Volunteer Satisfcation and Turnover Intention. The International Journal of Volunteer Administration, 28(3), 2028.

Robbins, T.W. (1997). Arousal systems and attentional processes. Biological psychology, 45(1), 57-71.

Ryan, R. M., Mims, V., \& Koestner, R. (1983). Relation of reward contingency and interpersonal context to intrinsic motivation: a review and test using cognitive evaluation theory. Journal of Personality and Social Psychology, 45, 736-750.

Shibli, S., Taylor, P., Nichols, G., Gratton, C., \& Kokolakakis, T. (1999). The characteristics of volunteers in UK sports clubs. European Journal for Sports Management, special issue: 11-27.

Sills,D.L. (1972). Voluntary associations: Sociological aspects. In D.L. Sills (Ed.) International encyclopaedia of the social Sciences, (16). New York: Cromwell, Collier and MacMillan.

Silverberg, K.E., Ellis, G.D., Whitworth, P., \& Kane, M. (2002). An Empirical Test of an" effects-indicator" Model of Volunteer Job Satisfaction. Retrieved from: http://citeseerx.ist.psu.edu/viewdoc/download?doi=10.1.1.599.8108\&rep=rep1\&type=pdf.

Silverberg, K.E., Ellis, G.D., Whitworth, P. \& Kane, M. (2002). An “effects-indicator" model of volunteer satisfaction: A functionalist theory approach. Leisure/Loisir, 27(3-4), 283-304.

Silverberg, K.E., Marshall, E.K., \& Ellis, G.D. (2001). Measuring job satisfaction of volunteers in public parks and recreation. Journal of Park \& Recreation Administration, 19(1).

Smith, M., Bruner, J., \& White, R. (1956). Opinions and personality. New York: Wiley.

Snyder, M. (1992). Motivational foundations of behavioral confirmation. In M. P. Zanna (Ed.), Advances in experimental social psychology, 25, 67-114. San Diego, CA: Academic Press.

Snyder, M. (1993). Basic research and practical problems: The promise of a "functional" personality and social psychology. Personality and Social Psychology Bulletin, 19, 251-264.

Stevens, E. S. (1991). Toward satisfaction and retention of senior volunteers. Journal of Gerontological Social Work, 16, 33-41.

Taylor, T., Doherty, A. \& McGraw, P. (2008). Managing people in sport organizations: A strategic human resource management perspective. Routledge.

Twynam, G.D., Farrell, J.M., \& Johnston, M.E. (2002). Leisure and volunteer motivation at a special sporting event. Leisure/Loisir, 27(3-4), 363-377.

Unlua, C., Serarslan, M.Z., Yamaner, F., \& Sahin, S. (2012). Comparing of human resources management sports enterprises and the other service enterprises. Social and Behavioral Sciences, 46(12), 4808-4812.

Wahba, M.A. \& Bridwell, L.G. (1976). Maslow reconsidered: A review of research on the need hierarchy theory. Organizational behavior and human performance, 15(2), 212-240.

Weerakoon, R.K. (2016). Human Resource Management in Sports: A Critical Review of its Importance and Pertaining Issues. Physical Culture and Sport. Studies and Research, 69(1), 15-21.

Wicker, P., \& Breuer, C. (2011). Scarcity of resources in German non-profit sport clubs. Sport management review, 14(2), 188-201.

Williams, P.W., Dossa, K.B., \& Tompkins, L. (1995). Volunteerism and special event management: A case study of Whistler's Men's World Cup of Skiing. Festival Management and Event Tourism, 3(2), 83-95.

Wong, L.P., Chui, W.H., \& Kwok, Y.Y. (2011). The volunteer satisfaction index: A validation study in the Chinese cultural context. Social indicators research, 104(1), 19-32.

Yousef, D.A. (2002). Job satisfaction as a mediator of the relationship between role stressors and organizational commitment: A study from an Arabic cultural perspective. Journal of Managerial Psychology, 17(4), 250-266. 


\section{Appendix: 01}

\section{Multiple Regression Analysis of Motivation and Satisfaction dimensions towards volunteer satisfaction Model Summary}

\begin{tabular}{|c|c|c|c|c|c|c|c|c|c|}
\hline \multirow[b]{2}{*}{ Model } & \multirow[b]{2}{*}{$\mathrm{R}$} & \multirow[b]{2}{*}{ R Square } & \multirow[b]{2}{*}{$\begin{array}{l}\text { Adjusted R } \\
\text { Square }\end{array}$} & \multirow{2}{*}{$\begin{array}{l}\text { Std. Error } \\
\text { of the } \\
\text { Estimate }\end{array}$} & \multicolumn{5}{|c|}{ Change Statistics } \\
\hline & & & & & $\begin{array}{l}\text { R Square } \\
\text { Change }\end{array}$ & F Change & df1 & df2 & $\begin{array}{c}\text { Sig. F } \\
\text { Change }\end{array}$ \\
\hline 1 & $.800^{\mathrm{a}}$ & .640 & .634 & .52407 & .640 & 107.818 & 3 & 182 & .000 \\
\hline \multicolumn{10}{|c|}{ a. Predictors: (Constant), Organisation_support, Group_Intergration, Empowerment } \\
\hline \multicolumn{10}{|c|}{ ANOVA ${ }^{\mathrm{a}}$} \\
\hline df & $\begin{array}{l}\text { Mean } \\
\text { Square }\end{array}$ & $\mathrm{F}$ & Sig. & & & & & & \\
\hline 3 & 29.612 & 107.818 & $.000^{\mathrm{b}}$ & & & & & & \\
\hline 182 & .275 & & & & & & & & \\
\hline \multicolumn{10}{|l|}{185} \\
\hline \multicolumn{10}{|c|}{ a. Dependent Variable: Overall Satisfaction } \\
\hline $\begin{array}{l}\text { b. Predic } \\
\text { Empowe }\end{array}$ & $\begin{array}{l}\text { rs: (Constar } \\
\text { hent }\end{array}$ & nt), Organisa & ation_suppo & roup_In & ion, & & & & \\
\hline
\end{tabular}

\begin{tabular}{|c|c|c|c|c|c|c|}
\hline \multicolumn{7}{|c|}{ Coefficients } \\
\hline \multirow[b]{2}{*}{ Model } & & \multicolumn{2}{|c|}{ Unstandardized Coefficients } & \multirow{2}{*}{$\begin{array}{c}\begin{array}{c}\text { Standardized } \\
\text { Coefficients }\end{array} \\
\text { Beta }\end{array}$} & \multirow[b]{2}{*}{$\mathrm{t}$} & \multirow[b]{2}{*}{ Sig. } \\
\hline & & $\mathrm{B}$ & Std. Error & & & \\
\hline \multirow[t]{6}{*}{1} & (Constant) & .843 & .195 & & 4.320 & .000 \\
\hline & Group_Intergration & & & & & \\
\hline & & -.013 & .067 & -.013 & -.195 & .846 \\
\hline & Empowerment & .571 & .097 & .551 & 5.870 & .000 \\
\hline & Organisation_support & & & & & \\
\hline & & .301 & .079 & .295 & 3.811 & .000 \\
\hline
\end{tabular}


Model Summary

\begin{tabular}{|c|c|c|c|c|c|c|c|c|c|}
\hline & \multirow[b]{2}{*}{$\mathrm{R}$} & \multirow[b]{2}{*}{ re } & \multirow[b]{2}{*}{ Adjusted R } & \multirow{2}{*}{$\begin{array}{l}\text { Std. Error } \\
\text { of the }\end{array}$} & \multicolumn{5}{|c|}{ Change Statistics } \\
\hline & & & & & $\begin{array}{l}\text { R Square } \\
\text { Change }\end{array}$ & F Change & $\mathrm{df} 1$ & $\mathrm{df} 2$ & $\begin{array}{l}\text { Sig. F } \\
\text { Chanoe }\end{array}$ \\
\hline
\end{tabular}

a. Predictors: (Constant), Love_of_Sport, Community_Involvment, Career_Orientation, Interpersonal_contact, Personal_Growth

\begin{tabular}{|c|c|c|c|c|c|c|}
\hline \multicolumn{7}{|c|}{ ANOVA $^{\mathrm{a}}$} \\
\hline \multicolumn{2}{|c|}{ Model } & $\begin{array}{l}\text { Sum of } \\
\text { Squares }\end{array}$ & $\mathrm{df}$ & Mean Square & $\mathrm{F}$ & Sig. \\
\hline \multirow[t]{3}{*}{1} & Regression & 47.964 & 5 & 9.593 & 18.740 & $.000^{\mathrm{b}}$ \\
\hline & Residual & 90.602 & 177 & .512 & & \\
\hline & Total & 138.566 & 182 & & & \\
\hline \multicolumn{7}{|c|}{ a. Dependent Variable: Overall_Satisfaction } \\
\hline \multicolumn{7}{|c|}{$\begin{array}{l}\text { b. Predictors: (Constant), Love_of_Sport, Community_Involvment, Career_Orientation, } \\
\text { Interpersonal_contact, Personal_Growth }\end{array}$} \\
\hline
\end{tabular}




\section{Coefficients}

\begin{tabular}{|l}
\multicolumn{7}{|c}{ Coefficients } \\
\hline \\
\end{tabular}

a. Dependent Variable: Overall_Satisfaction 